\title{
The German plan for rare diseases: a development in progress
}

\author{
Johann Mathias Graf von der Schulenburg \\ From 5th European Conference on Rare Diseases (ECRD 2010) \\ Krakow, Poland. 13-15 May 2010
}

In the year 2008, the German Federal Ministry of Health initiated a comprehensive study on the topic, "Activities for the improvement of health care for people with Rare Diseases". The study was motivated by recommendations on Rare Diseases by the European Council of Health Ministers. One important aim of the Council is to develop strategies and plans to improve the situation for patients with Rare Diseases at a national level.

In summer 2009, we published the aforementioned study about the situation of people with Rare Diseases in Germany, in which we made recommendations to improve their health care and life situation. One major conclusion was the creation of an institution working on a national plan for Rare Diseases in Germany.

In consideration of this result, the German Federal Government announced the foundation of NAMSE (National coalition for people with Rare Diseases) in March 2010. The main purpose of NAMSE is to finalise a German plan for Rare Diseases until the year 2013. Other goals are to concentrate current initiatives and to encourage pilot projects in the field of Rare Diseases. In order to secure the implementation of different perspectives and point of views, NAMSE's members are the most important stakeholders of the German health care system. This helps to ensure the feasibility of the national plan for Rare Diseases. The constituent meeting will take place in summer 2010. NAMSE is separated into a steering committee, which is the decision and controlling board, and working groups, which provide functional and continual work on particular questions. The activities of NAMSE are patient information/transfer of knowledge, diagnostics and therapy (including development of guidelines), health care and quality

Correspondence: jms@ivbl.uni-hannover.de

Centre for Health Economics, Hannover, Königsworther Platz 1, Hannover, 30167, Germany assurance, national and European networks of Reference and Expertise Centres, research as well as topics, suggested by the steering committee.

Published: 19 October 2010

doi:10.1186/1750-1172-5-S1-01

Cite this article as: Graf von der Schulenburg: The German plan for rare diseases: a development in progress. Orphanet Journal of Rare Diseases 2010 5(Suppl 1):01.

\section{Submit your next manuscript to BioMed Central and take full advantage of: \\ - Convenient online submission \\ - Thorough peer review \\ - No space constraints or color figure charges \\ - Immediate publication on acceptance \\ - Inclusion in PubMed, CAS, Scopus and Google Scholar \\ - Research which is freely available for redistribution \\ Submit your manuscript at www.biomedcentral.com/submit}

